\title{
Complementary Feeding Practices among Infant and Young Children in Southern Ethiopia: Review of the Findings from a Canada-Ethiopia Project
}

\author{
Carol Jean Henry ${ }^{1}$, Susan J. Whiting ${ }^{1} \&$ Nigatu Regassa ${ }^{2}$ \\ ${ }^{1}$ College of Pharmacy and Nutrition, University of Saskatchewan, Canada \\ ${ }^{2}$ Institute of Environment, Gender and Development, Hawassa University, Awassa, Ethiopia \\ Correspondence: Carol Jean Henry, College of Pharmacy and Nutrition, University of Saskatchewan, Canada. \\ E-mail: cj.henry@usask.ca
}

Received: June 30, 2015 Accepted: July 22, 2015 Online Published: September 15, 2015

doi:10.5539/jas.v7n10p29 URL: http://dx.doi.org/10.5539/jas.v7n10p29

\begin{abstract}
Collaborative projects have been undertaken between Hawassa University, Ethiopia and the University of Saskatchewan, Canada, with aims at mitigating protein and micronutrient malnutrition in Ethiopia. The main objective of this review is to assess complementary feeding practices of mothers in the project sites in Southern Ethiopia based on baseline data compiled by a total of nine independent studies. Findings revealed that complementary feeding practices are unacceptably poor in all the districts considered, despite the fact that larger proportion of mothers had knowledge on the timing and importance of complementary feeding to their child. The computed Diet Diversity Score (DDS) which was measured using 24-hour recall of children's intake, indicated that those with adequate DDS $(>4)$ were $<25 \%$ for 6 of 9 surveys, and the most frequently consumed food groups were low protein grains, roots and tubers. All the study zones had low wealth index and high household food insecurity, both of which corresponded with low DDS. The prevalence of both current and exclusive breast feeding practices were good (above 70\%). The prevalence of food secure households was very low in all the study districts and was reflected in very high levels of stunting and underweight among infants and young children. We conclude that future efforts should focus on both nutrition-based educational interventions to improve knowledge and practice of complementary feeding, and on nutrition-sensitive agriculture to increase access to affordable protein rich crops such as pulses, and curb the very high food insecurity levels through improving household income and wealth status.
\end{abstract}

Keywords: complementary feeding, diet diversity, infants, districts, Southern Ethiopia

\section{Background}

Infants and young children (IYC) are vulnerable to malnutrition because of their high nutritional requirements for growth and development (Blössner et al., 2005). They are particularly vulnerable during the transition period when complementary feeding begins, at six months (WHO-UNICEF, 2003). Widespread malnutrition leads to high incidence of diseases and deaths among children under five years of age (Black et al., 2013). Improving the quality of complementary food has been cited as one of the most cost effective strategies for improving health, reducing morbidity and mortality of young children. Nearly one third of child deaths could be prevented by optimal complementary feeding practices (Carlo et al., 2008; IBFAN, 2012).

In Ethiopia, children under 5 years of age suffer from unacceptably high prevalence of underweight, stunting, and wasting (44\%, 28\%, and 10\%, respectively) (Central Statistical Agency, 2012). Despite declines in neonatal mortality and under five mortality over the last few years from 26\% and 21\% (Sathyasusuman, 2011), the last Ethiopian Demographic and Health Survey (EDHS) reported 77 infant deaths per 1000 live births for the country (Central Statistical Agency, 2012), and 18\% of all infant deaths is attributable to poor feeding habits (Central Statistical Agency, 2011). This suggests that following 6 months of exclusive breast feeding, infants need to be given adequate complementary food, which is the timely introduction of safe and nutritional foods in addition to breast feeding (Gibson et al., 2009; Imdad et al., 2011). Such food should typically be provided to these children from 6 to 18-24 months of age (WHO, 2002), should be timely (should start at about 6 months), should be adequate and appropriate. 
Evidence shows that a very large proportion of women in Ethiopia do not practice optimal complementary feeding behavior. For example, only about half of the infants aged 6-8 months receive complementary foods (CF) (Aemro et al., 2011). Some of the gaps with regards to practicing appropriate complementary feeding include delay in introduction of the $\mathrm{CF}$, inadequate and less nutrient dense foods, poor access to food, and lack of knowledge (Central Statistical Agency, 2012). The situation is not different for Southern Ethiopia where the prevalence rates of the three nutritional status indicators- underweight, stunting and wasting were reported in 2011 to be as high as $28 \%, 44 \%$, and $8 \%$ respectively (Central Statistical Agency, 2012). Early studies suggested that infants and young children have little diet diversity, and they mostly consume local staple foodstuffs such as cereals and root crops (Mosha et al., 2000).

Studies on infant and child feeding practices in Southern Ethiopia are very few but may be used to assess the situation. Therefore, this review paper is prepared as an integral part of the ongoing collaborative projects between Hawassa University and the University of Saskatchewan, a Canadian International Food Security Fund (CIFSRF) project funded by the International Development Research Center and the Department of Foreign Affairs and Trade and Development (DFATD) Canada with aims at mitigating protein malnutrition in Ethiopia. To date the partner institutes have been successful in identifying health-nutrition challenges at the household level. These achievements are, however, limited in scope, geographic coverage, and require a scaling up of best practices identified by forming baseline information related to nutritional status and IYC feeding practices. The main objective of this review is to assess complementary feeding practices of mothers in the project sites in the region of Southern Nations and Nationalities Peoples Republic (SNNPR), along with associated factors, by pooling data and further analyzing nine surveys (case studies) funded and conducted by the partner institutions in the period from 2011 to 2014.

\section{Scope and Method}

\subsection{The Study Area and Population}

The CIFSRF project (2011-2014) conducted several small scale surveys and baseline data collections on human nutrition, diet and household wellbeing. Between 2011 and 2014, nine baseline surveys on women and child nutrition/diet were conducted in six districts of the project sites, which are located in two regions of Ethiopia: SNNPR and Oromiya.

Sidama zone, one of the most populous districts of SNNPR, has a total population of 2,954,136 and an area of $6,538.17 \mathrm{~km}^{2}$. More than $95 \%$ are rural inhabitants. The total households enumerated in 2007 were 592,539 (19.78\% of the regional population) which resulted in an average household size of 4.99 persons (Central Statistical Authority, 2007). A substantial area of the Sidama land produces coffee, a major cash crop in the region. The bulk of the population of the area are known to heavily depend on 'enset' (enset ventricosum), a starchy food. Four separate studies were conducted in three districts of the Sidama zone: Hula, Hawassa Zuria and Dale districts.

Wolayita zone is located in south eastern SNNPR. Damot Gale district, subdivided into 31 villages, is located in this zone, and has a high population density $\left(726\right.$ people $\left./ \mathrm{km}^{2}\right)$ (Central Statistical Authoroty, 2007). Mixed agriculture is the main economic activity of the zone. Recurrent drought is a major problem markedly reducing food production, income and assets. Limited availability of land among a growing number of households is resulting in decline in the size of land holdings (Elias, 2006). Hallaba district has a special zone status where the administration directly reports to the regional state. The total district population was 232,241 in 2007 (Central Statistical Authority, 2007). The district is subdivided into 79 rural and two urban kebeles/villages administratively with a total land area of $973.7 \mathrm{~km}^{2}$. The Adami Tulu Gido Kombolcha (Ziway area) is in East Shewa Zone of Oromia regional state. The main asphalt road connecting Hawassa town to Addis-Ababa bisects Adami Tullu Jido Kombolcha district.

\subsection{Inclusion Criteria}

This paper aims at bringing together nutrition related studies conducted in CIFSRF project sites (Southern Ethiopia) to form a baseline on complementary feeding practices of mothers on their young children (age 6-23 months).

A total of nine articles and/or academic theses were included. Many of the studies gathered data on multiple issues related to complementary feeding, nutritional status, and food consumption behavior of IYC whereas others addressed complementary feeding alone. Inclusion in this review was based on four criteria: (1) similarity in measuring complementary feeding (i.e. all studies used the FAO 2008 guideline); (2) conducted in the two regions of Southern Ethiopia; (3) collected the data from mother-child pair, infant and young children; and (4) 
using cases, cross sectional study design, and random sampling techniques that provided baseline data.

\subsection{Summary of Study Designs}

The reference population considered for all the studies was all mothers who had eligible young children (age 6 months to 23 months) and have been residents of the study areas for more than six months. Exclusion criteria for these studies were children of multiple pregnancies, children with evidence of chronic health problems such as diagnostically proven active tuberculosis, and symptomatic HIV/AIDS or children who had signs of illness such as persistent vomiting, coughing, diarrhea, or fever or acute signs such as runny nose, watery eyes, red eyes or redness around the lips.

Sample size of each individual surveys was determined using the single population proportion method with the inputs of $95 \%$ confidence level, and five to ten percent of the sample was added for possible non responses; the sample size of one of the studies (Tariku et al., 2015) was adjusted for design effects. Each case study employed random sampling techniques when selecting the mother-child pair following a house to house registration of eligible households.

The majority of studies used a survey questionnaire as its main data collection instrument wherein questions were adopted from the DHS surveys. Questions included socio-demographic characteristics, maternal and child characteristics, child feeding practices, and knowledge and practices related to complementary feedings. Most studies measured height, weight and Mid-Upper- Arm Circumference (MUAC) of the children in duplicate using trained professionals. Weight was measured using an electronic scale (Seca 770) with children wearing a light shirt of known weight. Length or height was measured to the nearest $0.1 \mathrm{~cm}$ using the Shorr measuring board without shoes. Mid-Upper- Arm Circumference (MUAC) was measured by using an arm circumference tape measure. Values for Z-scores for height (HAZ) and weight (WAZ) were calculated based on the WHO standard guidelines.

To determine the Diet Diversity Score (DDS), 24-hour recall were conducted with mothers regarding their child's intake. This score was calculated using food categories based on the FAO guidelines for measuring individual dietary diversity (FAO, 2008). All studies, except one (Mesfin et al., 2015) used the eight food categories (i.e. grains, roots and tubers; legumes and nuts; vitamin A rich fruits and vegetables; other fruits and vegetables; meat, poultry, fish; eggs; milk and milk products; and foods cooked with fats and/or oils), and affirmative responses in each was scored as 1: Score of DDS $>4$ per day is the minimum recommended level (FAO, 2008), and all the studies included in this review have used this cut point.

In six of the studies, additional information was collected using semi-structured focus group discussions guide in view of obtaining in-depth information on mothers' attitudes and practices on child feeding practices. For each individual studies, ethical approval was taken from Hawassa University Ethical Review Board. Informed consents were also provided by all the mothers included in the studies.

\subsection{Strategy for Data Synthesis}

In the course of analysis, attention was given to four important baseline information: household wealth and food security status, nutritional status, complementary feeding, and pulse based diet behaviors. The authors used published articles or reports when some of the raw data were not accessible. Both quantitative summaries and narrative synthesis was undertaken. 
Table 1. Summary of sampling and study designs for each selected surveys done in southern Ethiopia from 2011 to 2014

\begin{tabular}{|c|c|c|c|c|c|c|c|}
\hline Study & $\begin{array}{l}\text { Region/zone/ } \\
\text { district* }\end{array}$ & $\begin{array}{l}\text { Name of villages } \\
\text { sampled }\end{array}$ & Major crops grown & $\begin{array}{l}\text { District } \\
\text { population } \\
\text { in } 2007\end{array}$ & Type & Sample (n) & $\begin{array}{l}\text { Baseline } \\
\text { data } \\
\text { collected }\end{array}$ \\
\hline $\begin{array}{l}\text { Mesfin et al., } \\
2015\end{array}$ & $\begin{array}{l}\text { Damot Gale District, } \\
\text { Wolaita Zone, } \\
\text { SNNPR }\end{array}$ & Taba & $\begin{array}{l}\text { Potato, maize, haricot } \\
\text { bean, teff and sweet potato }\end{array}$ & 154,610 & $\begin{array}{l}\text { cross- } \\
\text { sectional } \\
\text { survey }\end{array}$ & $\begin{array}{l}128 \text { mother child } \\
\text { pair (age 6-23 } \\
\text { months) }\end{array}$ & 2011 \\
\hline $\begin{array}{l}\text { Tariku et al., } \\
2015\end{array}$ & $\begin{array}{l}\text { Hawassa Zuria } \\
\text { district, Sidama } \\
\text { Zone, SNNPR }\end{array}$ & $\begin{array}{l}\text { Dore Bafano, Jara } \\
\text { Gelelcha, Udo } \\
\text { Wotate and Doyo } \\
\text { Chale }\end{array}$ & $\begin{array}{l}\text { Maize, pepper and potato, } \\
\text { chat }\end{array}$ & 139,654 & $\begin{array}{l}\text { Cross- } \\
\text { sectional } \\
\text { survey }\end{array}$ & $\begin{array}{l}540 \text { households with } \\
\text { children } 6-18 \\
\text { months }\end{array}$ & 2012 \\
\hline $\begin{array}{l}\text { Zebdewos et al., } \\
2015\end{array}$ & $\begin{array}{l}\text { Damot Gale } \\
\text { District, Wolaita } \\
\text { Zone ,SNNPR }\end{array}$ & Taba and Gacheno & $\begin{array}{l}\text { Potato, maize, haricot } \\
\text { bean, teff and sweet potato }\end{array}$ & 154,610 & $\begin{array}{l}\text { Quasi } \\
\text { experimental }\end{array}$ & $\begin{array}{l}80 \text { mothers child } \\
\text { pair (age 6-23 } \\
\text { months ) }\end{array}$ & 2013 \\
\hline $\begin{array}{l}\text { Tezera et al., } \\
2015\end{array}$ & $\begin{array}{l}\text { Dale District, } \\
\text { Sidama Zone, } \\
\text { SNNPR }\end{array}$ & 6 villages & $\begin{array}{l}\text { Maize, barley, haricot } \\
\text { beans, cabbage, sweet } \\
\text { potatoes, coffee }\end{array}$ & 242,000 & $\begin{array}{l}\text { Cross } \\
\text { sectional }\end{array}$ & $\begin{array}{l}370 \text { mother child } \\
\text { pairs (age 6-23 } \\
\text { months ) }\end{array}$ & 2013 \\
\hline Regassa, 2014 & $\begin{array}{l}\text { Dale district, Sidama } \\
\text { zone, SNNPR }\end{array}$ & 12 villages & $\begin{array}{l}\text { Maize, barley, haricot } \\
\text { beans, cabbage, sweet } \\
\text { potatoes, coffee }\end{array}$ & 242,000 & $\begin{array}{l}\text { Cross } \\
\text { sectional }\end{array}$ & $\begin{array}{l}1094 \text { mothers child } \\
\text { Pair (age 6-23 } \\
\text { months ) }\end{array}$ & 2011 \\
\hline $\begin{array}{l}\text { Negash et al., } \\
2014\end{array}$ & $\begin{array}{l}\text { Hula, Sidama Zone } \\
\text { SNNPR }\end{array}$ & $\begin{array}{l}\text { Titicha and } \\
\text { Debicha }\end{array}$ & $\begin{array}{l}\text { Maize, wheat, barley, } \\
\text { potatoes, cabbage, and } \\
\text { broad bean (fava bean), } \\
\text { kocho (enset) }\end{array}$ & 130,433 & $\begin{array}{l}\text { Cross- } \\
\text { sectional } \\
\text { survey }\end{array}$ & $\begin{array}{l}197 \text { mother child } \\
\text { pairs (age 6-23 } \\
\text { months ) }\end{array}$ & 2012 \\
\hline $\begin{array}{l}\text { Ersino et al., } \\
2013\end{array}$ & Hallaba (SNNPR) & 2 villages & $\begin{array}{l}\text { Maize, teff, wheat, pepper, } \\
\text { haricot bean, sorghum, } \\
\text { millet, enset, chat }\end{array}$ & 232,241 & $\begin{array}{l}\text { Cross- } \\
\text { sectional }\end{array}$ & $\begin{array}{l}413 \text { mothers child } \\
\text { pairs (age 6-23 } \\
\text { months) }\end{array}$ & 2013 \\
\hline $\begin{array}{l}\text { Ersino et al., } \\
2013\end{array}$ & $\begin{array}{l}\text { Adami Tulu Gido } \\
\text { Kombolcha district } \\
\text { (Ziway area) } \\
\text { (Oromiya Region) }\end{array}$ & 1 village & $\begin{array}{l}\text { Teff, wheat, barley, } \\
\text { oil seeds }\end{array}$ & 189,202 & $\begin{array}{l}\text { Cross- } \\
\text { sectional }\end{array}$ & $\begin{array}{l}216 \text { mothers child } \\
\text { pairs (age 6-23 } \\
\text { months ) }\end{array}$ & 2013 \\
\hline $\begin{array}{l}\text { Kebebu et al., } \\
2013\end{array}$ & $\begin{array}{l}\text { Hula, Sidama Zone } \\
\text { SNNPR }\end{array}$ & Titecha & $\begin{array}{l}\text { Maize, wheat, barley, } \\
\text { potatoes, cabbage, and } \\
\text { broad bean (fava bean), } \\
\text { kocho (enset) }\end{array}$ & 130,433 & $\begin{array}{l}\text { Cross- } \\
\text { sectional } \\
\text { survey }\end{array}$ & $\begin{array}{l}169 \text { mother child } \\
\text { pairs (age 6-23 } \\
\text { months ) }\end{array}$ & 2011 \\
\hline
\end{tabular}

Note. ${ }^{*}$ District is administrative unit containing many villages (smallest admin). 
Table 2. Summary of percentage distribution of respondents for selected background characteristics (2011-2014)

\begin{tabular}{|c|c|c|c|c|c|c|c|c|c|}
\hline & $\begin{array}{l}\text { Mesfin et } \\
\text { al., } 2015 \\
(n=128)\end{array}$ & $\begin{array}{l}\text { Tariku et } \\
\text { al., } 2015 \\
(\mathrm{n}=540)\end{array}$ & $\begin{array}{l}\text { Zebdewos } \\
\text { et al., } 2015 \\
(n=80)\end{array}$ & $\begin{array}{l}\text { Tezera et } \\
\text { al., } 2015 \\
(\mathrm{n}=370)\end{array}$ & $\begin{array}{l}\text { Regassa, } \\
2014 \\
(n=860)\end{array}$ & $\begin{array}{l}\text { Negash et } \\
\text { al., } 2014 \\
(n=197)\end{array}$ & $\begin{array}{l}\text { Ersino et } \\
\text { al., } 2013 \\
(\mathrm{n}=413)^{*}\end{array}$ & $\begin{array}{l}\text { Ersino et } \\
\text { al., } 2013 \\
(\mathrm{n}=216)^{* *}\end{array}$ & $\begin{array}{l}\text { Kebebu et } \\
\text { al., } 2013 \\
(\mathrm{n}=169)\end{array}$ \\
\hline \multicolumn{10}{|l|}{ Sex of IYC } \\
\hline Male & 48.4 & 45.8 & 40 & 35 & 54.4 & 48.2 & 50.5 & 39.6 & 50.9 \\
\hline Female & 51.6 & 54.2 & 60 & 65 & 45.6 & 51.8 & 49.5 & 60.4 & 49.1 \\
\hline Mean age (SD) months & - & $\begin{array}{l}11.4 \\
(3.95)\end{array}$ & 12.8 & $\begin{array}{l}14.4 \\
(4.7)\end{array}$ & $\begin{array}{l}18.6 \\
(6.3)\end{array}$ & $\begin{array}{l}13.5 \\
(5.2)\end{array}$ & $\begin{array}{l}10.6 \\
(6.9)\end{array}$ & $\begin{array}{l}12.8 \\
(6.2)\end{array}$ & $\begin{array}{l}19.4 \\
(9.3)\end{array}$ \\
\hline \multicolumn{10}{|l|}{ Education of Mother } \\
\hline Literate & 50.8 & 61.4 & 52.5 & 47.1 & 43.7 & 38.7 & 19.6 & 29.5 & 38 \\
\hline Illiterate & 49.2 & 38.6 & 47.5 & 52.9 & 56.3 & 61.3 & 79.4 & 62.5 & 62 \\
\hline \multicolumn{10}{|l|}{ Employment of Mother } \\
\hline Employed & 21.9 & 27.7 & 26.9 & 26.5 & 52.9 & 35 & 6.5 & 10.6 & 13.6 \\
\hline Unemployed & 78.1 & 72.3 & 73.1 & 73.5 & 47.1 & 65 & 93.5 & 89.4 & 86.4 \\
\hline
\end{tabular}

Note. *: Hallaba (SNNPR); **: Adami Tulu Jedo Kombolcha (Ziway area) (Oromiya) districts.

\section{Results}

Table 2 presents summary of the background characteristics for the nine case studies. It can be observed that the representation of the subjects by gender ranges from ratio of 1:1 to 1:2 (Table 2). The mean age of the study population has little variation in six of the studies (ranging between 10-14 months), and the remaining one study (Kebebu et al., 2013) has a mean age of 19.4 with SD 9.3. In six of the studies, a significant proportion of the respondents were illiterate, only one study (Tariku et al., 2015) indicated significant percentage $(61.4 \%)$ of respondents were literate. Similarly, the proportion of unemployed respondents was very high for all of the studies considered, ranging between 47 to 94 percent. It was further noted that women in Hallaba and Gidokombolcha/Ziway districts were largely uneducated and unemployed.

\subsection{Household Wealth and Food Security Status}

Though it was not a major objective of all surveys conducted, some studies (Tezera et al., 2015; Regassa, 2014; Negash et al., 2014; Ersino et al., 2013), collected and analyzed wealth and food security status of the households surveyed. Household food security was measured by using tools developed by the Food and Nutrition Technical Assistance Project (FANTA). The nine question Household Food Insecurity Access Scale (HFIAS) used in several countries appeared to distinguish the food secure from the insecure households across different cultural contexts (Coates et al., 2007). The affirmative responses for the nine HFIAS questions are followed by frequency questions from which the four levels of food insecurity were computed based on the formula provided with HFIAS version 3 (Coates et al., 2007). Table 3 depicts the percent distribution by household and food security status.

It is noted from Table 3 that a substantial proportion of the households in all the four study areas Hula (Negash et al., 2014), Damot Gale (Zebdewos et al., 2015), Dale and Boricha (Regassa, 2014), Hallaba districts (Ersino et al., 2014) were facing food insecurity in one or the other form. The percentage reporting that they were food secure was less than 20 percent except for the Gidocombolcha district/Ziway where 33.3 percent of the households were food secure. The level of severity was high among Hallaba, Boricha and Damot Gale districts (Regassa, 2014; Negash et al., 2014; Ersino et al., 2013) sites. There was ample evidence suggesting high and sustained food insecurity across these areas over the three years study period.

There is high likelihood that food security is affected by the overall wealth status in the context of the study areas (Regassa \& Stoecker, 2012). Four of the surveys also measured household wealth index which was comprised of up to nine affirmative responses to ownership of selected household assets. The results summarized in Table 4 indicate that a larger proportion of households surveyed in Boricha and Dale district of the Sidama zone fell in the low wealth category (76.3\%) in 2011, and the figures for Hula (Negash et al., 2014) was much lower $(32.0 \%)$. 
Table 3. Summary of percentage of households in each Food Security Category

\begin{tabular}{|c|c|c|c|c|c|}
\hline & \multicolumn{4}{|c|}{ Household Food Security Status (\%) } & \multirow{2}{*}{ Total } \\
\hline & Food Secure & Mild food insecure & Moderate food insecure & Severe food insecure & \\
\hline Mesfin et al. $2015(n=128)$ & 8.6 & 0.8 & 18.8 & 71.9 & 100 \\
\hline Zebdewos et al 2015. $n=80$ & 16.3 & 5.0 & 33.2 & 45.3 & 100 \\
\hline Regassa $2014(n=1094)$ & 17.7 & 6.8 & 27.7 & 47.8 & 100 \\
\hline Negash et al. $2014(n=197)$ & 34.0 & 8.6 & 31.8 & 25.6 & 100 \\
\hline Ersino et al $2013(n=413)^{*}$ & 5.3 & 10.5 & 20.8 & 63.4 & 100 \\
\hline Ersino et al. $2013(\mathrm{n}=216) * *$ & 33.3 & 16.7 & 28.7 & 21.3 & 100 \\
\hline
\end{tabular}

Note. *: Hallaba district (SNNPR); **: Ziway district (Oromiya Region).

Table 4. Summary of percentage of households in each Wealth index category

\begin{tabular}{lllll}
\hline & \multicolumn{4}{c}{ Household Wealth Index (\%)* } \\
\cline { 2 - 5 } & Low & Medium & High & Total \\
\hline Tezera et al. 2015 $(\mathrm{n}=370)$ & 32.9 & 33.5 & 33.5 & 100 \\
Negash et al. 2014 $(\mathrm{n}=197)$ & 32.0 & 65.5 & 2.5 & 100 \\
Regassa 2014, $(\mathrm{n}=1094)$ & 76.3 & 21.2 & 2.5 & 100 \\
\hline
\end{tabular}

Note. *: Sum of affirmative responses for ownership of 8-9 common household assets: electricity, sewing machine, cart, mobile phone, flashlight, corrugated iron roofing, bike, radio and kerosene lamp.

\subsection{Nutritional Status}

The summary figures on nutritional status of IYC on Table 5 shows that almost all the districts studied were ranked suboptimal as they fell short of meeting many of the WHO guiding recommendations. The observed overall stunting and underweight for Hallaba (Ersino et al., 2013) and Wolaita (Mesfin et al., 2015), for instance, are prevalence estimates which WHO classifies as levels of "very high" and "high" public health concerns, respectively (WHO, 2008). Smallest prevalences were reported for the study conducted in Hula district of Sidama zone (Negash et al., 2014) (Table 5).

\subsection{Complementary Feeding Practice}

Nearly all the studies reported high prevalence of exclusive as well as high prevalence of current breast feeding practices. For instance, the study by Kebebu et al. (2013) for Hula District, Sidama Zone, found $72.8 \%$ of mothers were breastfeeding with reported frequency of eight times in 24 hours preceding the survey. In this study, pregnancy was the most likely reason for stopping breastfeeding, and two-thirds of the mothers $(65.7 \%)$ reported the $6^{\text {th }}$ month after birth as the time of starting complementary feeding. Similarly, Negash et al. (2013) and Tariku et al. (2015) reported 100\% breast feeding practices (12.8 times per 24 hour) and $88 \%$ for Hula and Hawassa Zuria districts of the Sidama zone respectively. In a study of 860 women in Dale and Boricha district of Sidama zone, Regassa (2014) documented that more than $87 \%$ of the respondents continued breast feeding until age 1 and about $86 \%$ reported continuing until age 2 .

Table 5. Nutritional status reported by six of the surveys (HAZ, HWZ and WAZ)

\begin{tabular}{llll}
\hline & Stunting $(\% \mathrm{HAZ}<-2)$ & Wasting $(\% \mathrm{WHZ}<-2)$ & Underweight $(\% \mathrm{WAZ}<-2)$ \\
\hline Mesfin et al. $2015(\mathrm{n}=128)$ & 38.3 & 5.5 & 17.2 \\
Tariku et al. $2015(\mathrm{n}=540)$ & 16.3 & 1.8 & 4.2 \\
Negash et al. $2014(\mathrm{n}=197)$ & 11.5 & 6.8 & 9.9 \\
Tezera et al. $2014(\mathrm{n}=370)$ & 22.3 & 4.7 & 13.5 \\
Ersino et al. $2013($ Hallaba, $\mathrm{n}=413)$ & 20 & 7 & 26 \\
Ersino et al. $2013($ Ziway, $\mathrm{n}=216)$ & 42 & 4 & 21 \\
Kebebu et al $2013(\mathrm{n}=169)$ & 22.5 & 4.7 & 8.3 \\
\hline
\end{tabular}

Note. $\mathrm{HAZ}=$ height for age Z-score; WAZ = weight for age Z-score; WHZ = weight for height Z-score. 
Diet diversity was measured in seven surveys using a 24-hour recall of children's intake. Table 6 shows that nearly all the studies found very low Diet Diversity Score (DDS): DDS $>4$ food groups is less than 25 percent for 7 over 8 studies. The survey conducted in Hula district (Negash et al., 2014) showed slightly higher DDS value $(32.5 \%>4$ food groups), while the lowest scores (about $8 \%>4$ food groups) were obtained for Hallaba and Ziway (Ersino et al., 2013). Further, there is little evidence of change in the DDS values during the period 2011 through 2014.

In Hula (Kebebu et al., 2013), the most frequently consumed food groups were grains, roots and tubers (97\%), followed by milk and milk products $(72 \%)$, and legumes/beans and nuts $(12 \%)$. None of the study participants consumed food groups for meat, poultry products and vitamin A rich fruits and vegetables the day before the study. Likewise, in the Damot Gale study (Mesfin et al., 2015), meat and egg consumption was low, and almost all children consumed foods prepared from grains, roots and tubers, and the majority ( $82 \%)$ also consumed milk, $43.7 \%$ consumed foods prepared from pulse crops. Higher percentage $(52.1 \%)$ of meat consumption and relatively lower $(32 \%)$ of grain and tuber were reported in one of the studies in Sidama zone (Regassa, 2014) compared to the figures reported by the other studies (Table 7).

Table 6. Diet Diversity Score (DDS) and proportion of infants and young children who Meet DDS of four or more food groups

\begin{tabular}{lll}
\hline Studies & Mean DDS & DDS $\geq 4$ food groups \\
\hline Mesfin et al.2015 $(\mathrm{n}=128)$ & 3.1 & 18 \\
Tariku et al. $2015(\mathrm{n}=540)$ & $2.33 \pm 0.58$ & 13.0 \\
Tezera et al $2015(\mathrm{n}=370)$ & 3.1 & 24.1 \\
Zebdewos et al.2015 $(\mathrm{n}=128)$ & 1.23 & 13.4 \\
Regassa 2014 $(\mathrm{n}=860)$ & $2.12 \pm 0.84$ & 42.4 \\
Negash et al. $2014(\mathrm{n}=197)$ & 1.2 & 32.5 \\
Ersino et al. $2013(\mathrm{n}=413)^{*}$ & 3.0 & 8.1 \\
Ersino et al. $2013(\mathrm{n}=216)^{* *}$ & 3.0 & 8.6 \\
Kebebu et al $2013(\mathrm{n}=169)$ & $2.1 \pm 0.69$ & - \\
\hline
\end{tabular}

Note. *: Hallaba (SNNPR); **: Ziway (Oromiya).

As most of the studies were conducted in the CIFSRF project areas, there was an attempt to look into the role of legume (pulse) crops in the diet of children in view of the fact that FAO/WHO/UNU (1985) recommends adding up to a maximum of $40 \%$ legumes to cereal-based complementary food for young children. Kebebu et al. (2013) reported that despite the growing of broad beans as a crop, little incorporation of this food into complementary feeding was practiced in which only about $12 \%$ of mothers reported giving bean or pea-based food to their children. The most commonly cited reason for not consuming these foods was lack of knowledge which was reported by $68 \%$ of the mothers. 
Table 7. Proportion of children who consume foods from different food groups

\begin{tabular}{|c|c|c|c|c|c|c|}
\hline Food Groups & $\begin{array}{l}\text { Ersino et } \\
\text { al., 2013 } \\
(n=314) *\end{array}$ & $\begin{array}{l}\text { Ersino et } \\
\text { al., } 2013 \\
(n=199)^{* *}\end{array}$ & $\begin{array}{l}\text { Kebebu et } \\
\text { al., } 2013 \\
(n=169)\end{array}$ & $\begin{array}{l}\text { Regassa, } \\
2014 \\
(n=860)\end{array}$ & $\begin{array}{l}\text { Tariku et } \\
\text { al., } 2015 \\
(n=540)\end{array}$ & $\begin{array}{l}\text { Mesfin et } \\
\text { al., } 2015 \\
(n=128)\end{array}$ \\
\hline Grains, roots and tubers & 86.7 & 94.0 & 97 & 32.1 & 99.4 & 94.5 \\
\hline Legumes and nuts & 29.8 & 26.6 & 12.4 & 41.2 & 39.9 & 43.7 \\
\hline Vitamin-A rich fruits \& vegetables & 56.0 & 56.3 & 0.0 & 65.6 & 25.2 & 53.1 \\
\hline Other fruits and vegetables & 70.9 & 75.9 & 6.5 & 68.1 & 51.5 & 69.5 \\
\hline Meat, chicken and fish & 0.6 & 4.0 & 0.0 & 52.1 & 00 & 18.7 \\
\hline Eggs & 4.7 & 4.0 & 5.3 & 44.1 & 26.4 & 26.6 \\
\hline Milk and milk products & 21.0 & 39.2 & 71.6 & 51.0 & 40.5 & 82.0 \\
\hline Foods cooked with fats and/or oils & - & - & 7.1 & 38.0 & - & - \\
\hline
\end{tabular}

Note. *: Hallaba (SNNPR) and Adami Tulu Jedo Kombolcha (Ziway area) (Oromiya) districts.

In the study of Damot Gale district (Mesfin et al., 2015), majority of mothers responded they never used soybean or lentil for complementary food preparation. One fourth of mothers indicated that they had no practice of using broad bean, haricot bean, kidney bean, pea, and chickpea in complementary food preparations. Nearly one third of mothers reported they used broad bean, haricot bean, kidney bean, pea, chickpea and lentil twice or less per month and lower consumption of soybean (19.5\%). The survey conducted in Hula district (Negash et al., 2014) further indicated pulse based consumption of 27 percent among the 197 children considered at the baseline.

\section{Discussion}

The main purpose of this review was to bring together evidence on complementary feeding practices in CIFSRF project areas (SNNPR and Oromia) in Ethiopia, and document such information for further intervention activities. The analysis revealed that the level of breast feeding practices is high in all the study districts ranging between 72 to 100 percent during the 24 hours preceding the survey. The mean breastfeeding frequency of the studies was also higher than the minimum recommended by the WHO, which is eight times per day (WHO, 2008). It is well documented that continued and frequent breastfeeding protects a child's health by reducing risk of morbidity and mortality in disadvantaged populations.

Complementary feeding practices are poor in all the districts considered, despite the fact that large proportion of mothers had knowledge on the timing and importance of complementary feeding to their child. In the study of Hula district, $78 \%$ of mothers previously received advice on complementary feeding, and $96 \%$ of them knew that continued breastfeeding during the complementary feeding period was important (Negash et al., 2014). While knowledge is one factor, studies (Tezera et al., 2105; Negash et al., 2014; Regassa, 2014; Ersino et al., 2013) indicate that poverty (wealth status) and food security are the underlining factors affecting the quality and quantity of diet of young children and other household members In these studies, both food security and wealth status were unacceptably low for the surveys whose data were available. Similar studies conducted in Southern Ethiopia (Girma \& Genebo, 2002; Teller \& Yimar, 2000) have also confirmed that household wealth was an important predictor for malnutrition.

Mothers in all the study areas most frequently consumed three to four of the 8 food groups such as grains, roots and tubers, milk and milk product, and beans and nuts. The frequency of consumption of common pulses (bean) was generally low in all the districts considered; only very small proportions of mothers reported its use once or more per day. The most commonly cited reason for not consuming pulse based foods was lack of knowledge among mothers. The findings of some of the surveys indicates that mothers' knowledge source is extension workers (Negash et al., 2014) as access to information through radio was reported by only 17.8 percent of the respondents.

Earlier studies, prior to 2011, conducted in the region, also documented nearly similar levels and patterns on complementary feeding practices. For instance, a study by Gibson et al. (2009) indicated that the diets consumed by infant and young children age 6-23 months were monotonous with low dietary diversity; pieces of un-mashed maize bread was the main complementary food consumed. The 2005 Ethiopian Demographic and Health Survey (EDHS) results on infant and young children (6-23 months) accounted that the proportion who consumed foods 
made from grains was $70 \%$ which is the highest compared with the consumption of other types of solid or semisolid foods; and at age 6-23 months, only $10 \%$ of children were reported to consume meat, fish, egg (Central Statistical Authority, 2007). The same survey indicated 43.7 and 54.3 percent consumption of foods prepared from pulse crops for age groups 12-23 months and children aged 24-59 months respectively. Similar high non-consumption of pulse was reported in another study conducted in Ethiopia (Central Statistical Agency, 2012). A community assessment on "timely complementary feeding" in three regions of Ethiopia (Amhara, Oromia and SNNPR) documented that only 39\% of the children aged 6-9 months received "semi-solid or solid foods" in addition to breast milk in the 24 hour preceding the survey. The rate for Southern region was $61 \%$ (Belaineh \& Berhane, 2011).

Limitations of this review of studies is some inconsistency in data collection tools for eliciting information related to complementary feeding and associated factors. However, by bringing the various surveys together, this piece of work contributes to our understanding of the depth and width of the problem and forms the baseline information at aggregate level for the intervention activities ahead. Our data confirmed that infants and young children have little diet diversity, and they mostly consume local staple foodstuffs such as cereals and root crops. Finally, it is noted that future efforts should focus on a nutrition educational intervention that could address the knowledge and practice gaps in complementary feeding, increase access to affordable protein rich crops such as pulses, curb the very high food insecurity levels trough improving household income and wealth status.

\section{Acknowledgments}

We are grateful to the International Development Research Center (IDRC), and the Department of Foreign Affairs and Development Canada for providing financial support for the project through the Canadian International Food Security Research Fund (CIFSRF) and the partnership team from the University of Saskatchewan and Hawassa University.

\section{References}

Aemro, M., Mesele, M., Birhanu, Z., \& Atenafu, A. (2011). Dietary diversity and meal frequency practices among infant and young children aged 6-23 months in Ethiopia: A secondary analysis of Ethiopian Demographic and Health Survey 2011. Journal of Nutrition and Metabolism, 2013, Article ID 782931. http://dx.doi.org/10.1155/2013/782931

Belaineh, G., \& Berhane, Y. (2011). Children who were vaccinated, breast fed and from low parity mothers live longer: A community based case-control study in Jimma, Ethiopia. BMC Public Health, 11, 197. http://dx.doi.org/10.1186/1471-2458-11-197

Black, R. E., Victora, C. G., Walker, S. P., Bhutta, Z., Christian, P., Onis, M., \& Ezzati, M. (2013). Maternal and child undernutrition and overweight in low-income and middle-income countries. Lancet, 382(9890), 427-451. http://dx.doi.org/10.1016/S0140-6736(13)60937-X

Blössner, M., \& de Onis, M. (2005). Malnutrition: Quantifying the health impact at national and local levels. WHO Environmental Burden of Disease Series, No.12. Geneva: World Health Organization.

Carlo, A., Tamas, D., Fewtrel, M., Goulet, O., Kolacek, S., Koletzko, B., et al. (2008). Complementary feeding: commentary by European Society for Pediatric Gastroenterology, Hepatology, and Nutrition. Journal of $\begin{array}{llll}\text { Pediatric Gastroenterology and } & \text { Nutrition, }\end{array}$ http://dx.doi.org/10.1097/01.mpg.0000304464.60788.bd

Central Statistical Agency. (2011). Ethiopia Demographic and Health Survey 2010. Addis Ababa, Ethiopia/Calverton, MD, USA: Central Statistical Agency/ORC Macro.

Central Statistical Agency. (2012). Ethiopian Demographic and Health Survey 2011. Addis Ababa, Ethiopia and Calverton, Maryland, USA: Central Statistical Agency and ICF International.

Central Statistics Authority. (2007). Summary and Statistical Report of the 2007 Population and Housing Census Results. Addis Ababa, Ethiopia.

Coates, J., Swindale, A., \& Blinsky, P. (2007). Household Food Insecurity Access Scale (HFIAS) for Measurement of Household Food Access: Indicator Guide (v.3). Washington D.C: Food and Nutrition Technical Assistance Project, Academy for Educational Development.

Elias, G. (2006). Challenges and coping strategies for drought-induced food shortage. Humbo Worda, SNNPR, AAU, Addis Ababa.

Ersino, G., Henry, C. J., \& Zello, G. (2013). Suboptimal feeding practices and high levels of under nutrition 
among infants and young children in the rural communities of Hallaba and Ziway, Ethiopia. Food and Nutrition Bulletin. Submitted.

FAO. (2008). Guidelines for measuring household and individual dietary diversity (Version 4). Rome, Italy.

FAO/WHO/UNU. (1985). Energy and Protein Requirements. Report of a Joint FAO/WHO/UNU Expert Consultation. Tech. Rept. Ser. No. 724. World Health Organization: Geneva, Switzerland. 1985.

Gibson, R. S., Abebe, Y., Hambidge, M. K., et al. (2009). Inadequate feeding practices and impaired growth among children from subsistence farming households in Sidama, southern Ethiopia. Journal of Maternal and Child Nutrition, 5, 260-275. http://dx.doi.org/10.1111/j.1740-8709.2008.00179.x

Girma, W., \& Genebo, T. (2002). Determinants of Nutritional Status of Women and Children in Ethiopia. Calverton, Maryland, USA: ORC Macro.

Imdad, A., Yakoob, M. Y., \& Bhutta, Z. A. (2011). Impact of maternal education about complementary feeding and provision of complementary foods on child growth in developing countries. BMC Public Health, 11(Suppl. 3), S25. Retrieved from http://dx.doi.org/10.1186/1471-2458-11-S3-S25.

International Baby Food Action Network (IBFAN). (2012). Report on the situation of infant and young child feeding in Liberia. The convention on the rights of the child, session 61, September-October 2012. Geneva. IBFAN-GIFA.

Kebebu, A., Whiting, S. J., Dahl, W. J., Henry, C. J., \& Abegaz, K. (2013). Formulation of a Complementary Food Fortified with Broad Beans (Vicia faba) in Southern Ethiopia. African Journal of Food Agriculture Nutrition and Development, 13(3). Retrieved from http://www.ajfand.net/Volume13/No3/Afework13035.pdf

Mesfin, A., Henry, C. J., Kaler, A., Girma, M., Whiting, S. J. (2015). Use of pulse crops in complementary feeding of 6-23 month old infants and young children at Taba kebele, Damot Gale District, Southern Ethiopia. Journal of Public Health in Africa. In press.

Mosha, T. C. E., Laswai, H. S., \& Tetens, I. (2000). Nutritional composition and micronutrient status of homemade and commercial weaning foods consumed in Tanzania. Plant Foods and Human Nutrition, 55(3), 185-205. http://dx.doi.org/10.1023/A:1008116015796

Negash, C., Belachew, T., Henry, C. J., Kebebu, A., Abegaz, K., \& Whiting, S. J. (2014). Nutrition education and introduction of broad bean based complementary food improves knowledge and dietary practices of caregivers and nutritional status of their young children in Hula, Ethiopia. Food and Nutrition Bulletin, $35(4), 480-48$.

Regassa, N. (2014). Infant and child feeding practices in a food secure zone in Southern Ethiopia. KONTAKT, $16(2), 216-222$.

Regassa, N., \& Stoecker, B. (2012). Contextual Risk Factors for Maternal Malnutrition in a food insecure zone in Southern Ethiopia, Journal of Biosocial Science, 44, 537-548. http://dx.doi.org/10.1017/S002193201200017X

Sathyasusuman, A. (2011). Neonatal and post-neonatal mortality decline in Ethiopia: Evidence from DHS 2005. Revista De Cercetare Si Interventie Sociala, 32, 44-62.

Tariku, B., Whiting, S. J., Mulualem, D., \& Singh, P. (2015). Application of health belief model to teach complementary feeding messages in Ethiopia. Ecology of Food and Nutrition. In press. http://dx.doi.org/10.1080/03670244.2015.1049344

Teller, H., \& Yimar, G. (2000). Levels and determinants of malnutrition in adolescent and adult women in southern Ethiopia. Ethiopian Journal of Health Development, 14, 57-66.

Tezera, F. (2015). Dietary calcium intake and sunlight exposure among children aged 6-23 months in Dale woreda, southern Ethiopia. Master's thesis (Unpublished), Hawassa University.

WHO. (2008). Indicators for assessing infant and young child feeding practices: Conclusions of a consensus meeting held 6-8 November 2007 in Washington, DC, USA. Part 1: Definitions. Geneva: World Health Organization. Retrieved June 16, 2015, from http://whqlibdoc.who.int/publications/2008/9789241596664_e ng.pdf

WHO-UNICEF. (2003). Global strategy for infant and young child feeding. Geneva: World Health Organization. Retrieved from http://whqlibdoc.who.int/publications/2003/9241562218.pdf 
World Health Organization (WHO). (2002). Report of informal meeting to review and develop indicators for complementary feeding. Washington, DC.

Zebdewos, A., Singh, P., Birhanu, G., Whiting, S. J., Henry, C. J., \& Kebebu, A. (2015). Formulation of micronutrient rich complementary food by using locally available amaranth, chickpea and maize. African Journal of Food Agriculture Nutrition and Development. In Press.

\section{Copyrights}

Copyright for this article is retained by the author(s), with first publication rights granted to the journal.

This is an open-access article distributed under the terms and conditions of the Creative Commons Attribution license (http://creativecommons.org/licenses/by/3.0/). 